Book Chapter

\title{
The Evolution of the Romanian Renewable Energy Market: A Critical Assessment
}

Nicolae Marinescu*

MTSAI Department, Faculty of Economic Sciences and Business Administration, Transilvania University of Brasov, Romania

*Corresponding Author: Nicolae Marinescu, MTSAI Department, Faculty of Economic Sciences and Business Administration, Transilvania University of Brasov, 500036 Brasov, Romania

Published April 21, 2021

This Book Chapter is a republication of an article published by Nicolae Marinescu at Energies in December 2020. (Marinescu, N. Changes in Renewable Energy Policy and Their Implications: The Case of Romanian Producers. Energies 2020, 13, 6493. https://doi.org/10.3390/en13246493)

How to cite this book chapter: Nicolae Marinescu. The Evolution of the Romanian Renewable Energy Market: A Critical Assessment. In: Fan Xiao, editor. Advances in Energy Research: $2^{\text {nd }}$ Edition. Hyderabad, India: Vide Leaf. 2021.

(C) The Author(s) 2021. This article is distributed under the terms of the Creative Commons Attribution 4.0 International License(http://creativecommons.org/licenses/by/4.0/), which permits unrestricted use, distribution, and reproduction in any medium, provided the original work is properly cited. 


\section{Abstract}

This research assesses the evolution of the renewable energy market in Romania. Attracted by a generous support scheme, foreign and domestic investors flocked to the market. Subsequently, the sector witnessed remarkable progress, especially in the wind power category. Romania closed in rapidly on the national target set by the European Union concerning the share of the country's energy consumption from renewable sources. However, frequent changes in the support scheme and in the regulations issued by public authorities led to chaos. The aim of the paper is to emphasize the evolution of renewable energy policy in Romania, to investigate the incentives and their effects, and to critically assess the impact of the changes on renewable energy producers. It highlights, by means of an exploratory study and several interviews with executives of renewable energy companies, the challenges and shortcomings of policymaking. The main finding is that the revision of the subsidy scheme and the changes in energy policy that followed are the major determinants for the declining financial performance of renewable energy producers. Some recommendations for improved policymaking so as to reestablish the trust of investors and to foster the sustainable development of the energy sector are suggested in the final part.

\section{Keywords}

Renewable Energy; Energy Market; Support Scheme; Green Certificates, Energy Policy

\section{Introduction}

Inside the European Union (EU), since a complex process of energy reform has been initiated, some of the member states saw a remarkable and even spectacular increase in the development of renewable energy sources [1]. The use of renewable energy has been encouraged and supported by the EU to reduce greenhouse gas emissions, achieve energy policy goals of 
sustainability, security and increased efficiency, and to reduce its dependency on foreign energy suppliers.

According to the Europe 2020 Strategy, the EU has set three main objectives related to climate change and energy: to achieve a reduction of $20 \%$ in greenhouse gas emissions from the 1990 level; to produce $20 \%$ of energy consumed from renewable sources; and to raise energy efficiency by $20 \%$ by the year 2020 [2].

By 2018, Romania already ranked seventh among EU member states when considering electricity generated from renewable energy [3]. Among the 'green' sources, hydro power is the most significant in the EU and in Romania, followed by wind power and then solar power. Other renewable energy sources for generating electricity include biogas, wood, waste, and geothermal energy [4,5]. The balanced mix of Romania's energy resources and its relative energy independence decrease the risks of supply shortages and contribute to a better response against climate change.

The aim of this paper is to critically assess the evolution of the Romanian renewable energy policy together with the changes in the regulations that transformed the market, analyze the impact of these changes on the actors involved, and formulate recommendations for future policymaking.

The research contributes to the present knowledge in the field in several ways. This paper takes a fresh look at the renewable energy sector in Romania, after the major changes in policy regulations were implemented. The situation of energy producers from renewable sources is analyzed from various perspectives, stressing the impact of the changing landscape in energy policy on the market in a detailed manner. Moreover, some specific recommendations for improved policymaking are suggested, so as to develop the sector sustainably. The novel character of the paper stems from combining the exploratory part of data gathering with empirical information from senior managers of companies actively involved in the market. 
The paper is structured in the following sections: next, the literature review highlights some of the most important propositions regarding the development of renewable energy policies in several EU countries and especially in Romania, their main characteristics, and the incentive schemes that were implemented by the governments. The data, the sources, and the methods used for research are detailed in the next section. The main results of the research are presented in the fourth section. The investigation reveals the major challenges faced by renewable energy producers, together with the shortcomings of policymaking in this field. The concluding section pinpoints the contribution of this study to the existing literature and makes some suggestions for improving decision-making in terms of renewable energy policy.

\section{Literature Review}

As one of the key features of European integration, energy policy is characterized by three main policy issues: market deregulation, energy security and climate change. Inside the Energy-Climate package of the European Union, renewable energy is a major element for the desired move towards an economy running on low carbon. Apart from its own stance and plans directed towards tackling climate change, the EU has also promoted, advocated, and adhered to the Paris Agreement, which it ratified in October 2016. The agreement, signed in December 2015 by almost 190 countries, was the first global, legallybinding climate change framework. With its ambitious long-term goals of limiting rising global temperatures, as well as setting a peak for global emissions as soon as possible, the Paris Agreement has supplemented the EU's plans of reducing greenhouse gas emissions by a minimum of $40 \%$ by the year 2030 .

To solve climate change issues in an efficient manner also needs consistent financing to reach the objectives on part of the countries. The EU is the main contributor of public finance inside the Paris Agreement. It has already passed the necessary legislation connected to the agreement. It remains firmly determined in its implementation, so the EU member states, 
including Romania, have incorporated these changes into their own climate policies.

Under the Climate Action Regulation, with its main component being the surface transportation, the regulations are directed towards the EU member states, each country having specific targets set for the period 2021-2030, with the role of a national carbon budget. Romania has already submitted its draft national energy and climate plan for the above period and is due to bring completions according to the assessment by the European Commission.

During all the modern climate change conferences, the importance of carbon pricing to reduce emissions, as well as decarbonization through the wider use of electric vehicles, were highlighted. Together with higher energy efficiency and more energy derived from renewable sources, electric transportation is a critical must for a cleaner world and a revolution in technology. The role of electric vehicles is widely recognized for accelerating the transformation of the transport system and for greenhouse gas mitigation, in line with the provisions of the Paris Agreement and the Climate Package of the EU.

In order to achieve a higher share of electricity from renewable sources in the EU, various support mechanisms were put in place during the years: investment support, fixed price instruments, fixed premium instruments, and quotas developed around tradable green certificates or auctions [6]. Muhammed and Tekbiyik-Ersoy (2020) in their overview of energy policies in three leading countries outside the EU, namely China, United States and Brazil, found evidence for a strong link between subsidy schemes and the development of renewable energy in most cases [7].

On the technical implementation side, the two main policy instruments for developing renewable energy consist of the feedin tariff system and the renewable portfolio system. As explained by Balibrea-Iniesta (2020), the feed-in tariffs mean a payment that comprises a bonus over the wholesale market price of electricity, while the renewable portfolio system requires that a 
specific share of electricity producers' production stems from renewable sources [8]. A comprehensive assessment of the evolution of feed-in tariffs in the largest European Union member states was made by Jacobs, 2016 [9].

The forerunner in applying renewable energy policy instruments in the EU was Germany. The first feed-in law was implemented in 1991, leading to a market breakthrough in wind power. Germany was a pioneer in renewable energy, becoming the global leader for installed wind capacity as early as 2003 [10]. According to Wustenhagen and Bilharz (2006), no country was so successful in increasing new capacities as fast as Germany [11].

The growth of energy generated from renewable sources was backed by strong policy support, including investment subsidies, soft loans, and tax exemptions in its early years. Starting in 2015, a market premium scheme based on competitive auctions replaced feed-in tariffs for most installations. Only small power plants still benefit from a feed-in tariff. "Energiewende" (energy transformation), the major plan to reform the energy system, has been at the heart of German energy policy for the last decade. It aims to push Germany towards an even higher energy supply from renewable sources and to phase out electricity derived from nuclear power by 2022 [12].

As Renn and Marshall (2016) underline, implementing policy in favor of renewable sources was not straightforward in Germany. The process was driven by protest, planning, market opportunities, political commitments, and contingent events [13]. In a similar vein, Raybould et al. (2020) demonstrate, for the particular case of the U.K., that while governmental support is paramount for developing renewable energy technologies, businesses and the wider public are also needed to transfer the renewable energy innovations to the market [14].

Driven by the German model of success and by its own commitments towards the EU, Spain also saw a spectacular rise in renewable energy production over the last few decades. This was backed by a favorable funding scheme from 1997 onwards. 
Successive cutbacks in incentives came in the late 2000s. The scheme was interrupted in 2009 as a side effect of the economic crisis. Public aid resumed after the crisis was over, based on the granting of incentives, continuing Spain's success in wind and solar power installations. Most authors agreed however that the growth of renewable energy in Spain is heavily dependent on policy support [15,16]. As Martinez Alonso et al. (2016) demonstrate in their comprehensive overview of the Spanish energy policy, as soon as the government removed the financial incentives for renewable energy, the whole sector entered into a paralysis [17].

Newer EU member states, such as Poland, also adjusted their energy policy in order to achieve the targets set by the European Union in terms of energy efficiency and sustainability. After relying on a promotion system based on green certificates, which encouraged biomass as its main source of renewable energy generation, Poland changed its energy policy in 2016 with a Renewable Energy Act. This regulation introduced two new mechanisms for driving up renewable energy investments. One is an auction mechanism to substitute green certificates and the other consists of feed-in tariffs. The new system is aimed to encourage the most cost-effective technologies [18].

After joining the European Union in 2007, Romania embarked on a long journey of reforming and modernizing its previously fully state-owned energy sector. At the respective moment, according to Bianco et al. (2014), once Romania became a member state of the EU, three main points needed to be addressed in terms of energy policy in order for Romania to act as a defining participant in the regional energy market: obsolete power plants, development of cross-border interconnections, and the impact of energy policy reform [19].

Romania also had its own energy objectives, as Haar and Marinescu (2011) observed, apart from EU regulations-namely to upgrade and expand total generation capacity, infrastructure and international connection, to increase current energy efficiency and diminish energy intensity by investing in technological upgrading. These goals required the restructuring 
and improvement of many categories in the energy sector, namely production, transport, and distribution. In order to comply with the intrinsic financial limitations, the country attracted foreign and domestic private investments [20].

Energy utilities were mostly privatized during the years 20042006. The gas distribution company was split into two regional divisions (North and South) and both were privatized with foreign investors. The national electricity distribution company was split into eight distinct divisions. Five of these divisions were privatized with foreign investors from the EU member states. For the remaining three, the privatization process was postponed on an undefined term. The main electricity generators-for hydro power and nuclear power-remain in state property. The same is valid for the power grid company, Transelectrica.

Once the targets for increased efficiency and cleaner energy generation were set by the EU, various authors in the literature started to investigate the paths of sustainable development through which Romania could direct itself towards meeting the renewable energy challenge.

Dusmanescu et al. (2014) proposed an energetic mix from various sources to ensure the necessary technical potential for the year 2020 in an attempt to develop a possible outlook for the implementation of different renewable energy sources in Romania [21]. Wind power took the first place among options, the choice which turned out to be realistic.

Cirstea et al. (2018) produced comprehensive overview research of the different types of renewable energy sources available in Romania. Their preliminary prediction for the best scenario regarding the sector for future decades is to develop the perspective of using biomass in various ways that could prove efficient [22].

Whereas hydro power plants were built in communist times and little capacity has been added, the most progress has been registered for wind energy. As highlighted by Dragomir et al. 
(2016) in their account of the development of the Romanian wind energy sector, the country increased from just $14 \mathrm{MW}$ of installed capacity in 2009 to around $3000 \mathrm{MW}$ of installed capacity in 2015 [23].

As a confirmation of the country's outstanding evolution in the wind energy sector, consulting firm Ernst \& Young ranked Romania as the 10th most attractive country included in its global Country Attractiveness Index ranking in 2012, branding it as 'the shining star of renewable energy in Eastern Europe' [24].

The positive evolution of the electricity sector in Romania, as one of the important players in the region, is acknowledged in the literature $[23,25,26]$. Busu et al. (2019) also demonstrated by means of a linear correlation for several countries in the Eastern European region that prices may converge once the interconnection of electricity grids between countries is higher [26].

The most comprehensive overview of policymaking on this particular subject in the literature was produced by Zamfir et al. (2016), who performed a review of the public policies and legislation put in place to foster the evolution of renewable energy in Romania over a decade [25]. The authors assessed the main issues, measures, and results of the public energy policy in Romania, presenting the mechanism of green certificates, and highlighting the various changes in Romanian subsidy schemes over time.

Campeanu and Pencea (2014) also assessed the main determinants of the development of the renewable energy market in Romania. They showed that at that particular moment in time, Romania implemented one of the most generous policies in comparison to other countries in the EU related to stimulating the production of renewable energy, but at the same time, negative signs were starting to appear on the horizon; policymakers beginning to withdraw some of the incentives and changing regulations in the field [27]. 
Duhaneanu and Marin (2013) pointed out very well that several problems are still very challenging for renewable energy developers in Romania to cope with, namely bureaucracy and barriers concerning the connection to the network, and changes in energy policy related to green certificates [28]. The linkage between the evolution of investments in the sector leading to the dynamic character of the market and the interest of public authorities to conserve the stability of the energy market for different players, brought several serious bottlenecks.

Various authors and independent energy consultants pinpointed that the battle of interests between renewable energy producers and traditional state-owned utilities referred mainly to the firstmover possibility of introducing energy into the network, possible overloads that were generated in intervals of high demand and increased fluctuation of prices; a clash which led to disputes and heavy lobbying among policymakers [29].

\section{Methodology of the Research}

The methods used for this study included an exploratory analysis, based on press releases, official government policy documents, and market insider reports, with semi-structured interviews with senior executives from selected companies in the renewable energy sector. The methodology comprises four stages. Firstly, the targets of the European Union in terms of renewable energy are briefly described. Secondly, the characteristics of the regulatory framework of the Romanian energy policy are analyzed. Thirdly, the implications of the changes in the support mechanism are investigated and critically assessed. Finally, the market situation is derived from the opinions expressed during the interviews by managers of renewable energy companies.

In the first phases, major published articles, internal company publications, annual reports, industry analyses, and business reference materials from the last two decades were all thoroughly researched in order to provide a detailed insight into the workings of the energy market, with a special focus on the case of Romania. 
In the last phases, 16 interviews were conducted with senior managers of renewable energy producers. In Romania, there are currently around 700 renewable energy companies actively in operation. The vast majority of them are very small solar or biomass producers with installed capacities of less than $5 \mathrm{MW}$.

The research group selected for this study was based on the snowball sampling technique, by which participants referred the researcher to others with the same characteristics, consisted of around 25 companies. In non-probability sampling, the attempt is not driven towards generating a representative sample. However, from the managers that responded positively, four of them represented large producers, seven of them medium-sized producers and five of them small producers, so the sample had a balanced distribution.

Of the 16 companies, 11 were under foreign ownership and 5 under Romanian ownership. The nationality of the investors did not bear any significant relevance in the opinions expressed, but was consistent with the distribution of ownership in the sector nationwide. The combined market share of the producers in the research group totaled $27.8 \%$ of installed power in Romania, which was fairly consistent. The individual interviews were conducted on the phone, in September-October 2019, each lasting between 15 and $25 \mathrm{~min}$. The discussions during the interviews were based on a list of questions that came out of the aim of the research. The responses of the interviewed senior managers were transcribed, and the data were synthesized into content analysis findings on the impact of the changes in Romanian energy policy and their outcomes.

The strengths of this type of research reside in obtaining in-depth information about the workings of the market and the impact of legal measures on producers, the reasons that lead to several decisions taken by managers, as well as identifying latent aspects that are relevant for the profound understanding of the phenomena under investigation. The weaknesses of the qualitative research are that some variables are non-measurable with hard numbers, and these results are more difficult to interpret and analyze; they depend on the experience of the 
researcher. The main limit of this type of research comes from the impossibility of extending the results to a larger scale.

The author is aware that a certain bias may appear in the answers of the managers that were interviewed, but the opinions expressed by them were confronted and double-checked with a thorough reading of declarations in the press, insider reports and market analysis documents. Thus, data were compared across multiple sources and from different perspectives to ensure a higher degree of reliability. It also turned out that the opinions of the managers were fairly consistent and converged with those of the patron organization in the field, which reunites more than 100 such producers of renewable energy.

According to its strategy, the European Union tried to cover $20 \%$ of energy consumption from renewable sources until 2020, a concept which carried both environmental and economic reasoning [30], in order to reach a long-term sustainable development [31]. The target was set between member states of the EU by means of national action plans.

Progress was spurred by the compulsory targets for a growing energy share from renewable sources as per the Directive no. 28/2009 issued by the European Commission (EC). This move is in line with a general trend worldwide to replace traditional energy resources with renewables, by means of subsidies, market integration schemes, support mechanisms and various other incentives [32-34].

Concerning the types of energy sources, wind power registered the highest dynamics within the EU. In 2016, wind energy replaced coal, to rank second among the types of power generation capacity after gas. Moreover, 16.8 GW of additional wind power capacities were installed in 2017, making it a record year [35]. As a consequence of this positive development, the share of renewable energy in the total consumption of the EU almost doubled between 2004 and 2018, from $9.6 \%$ to $18.9 \%$ [36]. 
EU ambitions towards covering more of the necessary energy from renewable sources grow even higher. In an open letter to the European Commission, the ministers of energy and environment from six EU member states called for a $100 \%$ renewable energy scenario to be included in long-term forecasts for 2050 , especially $100 \%$ in the electricity sector [37. Globally, most of the new energy generation capacity comes from renewable technologies [38].

The cumulative share of renewable energy sources in Romanian gross electricity production currently reaches $41.3 \%$, as depicted by the green slices in Figure 1 [39]. This share is higher than the EU average (32.2\%). Thus, Romania ranks seventh in the European hierarchy after Austria, Sweden, Denmark, Latvia, Portugal and Croatia [40]. The traditional energy sources account for a total share of $58.7 \%$ of total electricity production (see the yellow slices in Figure 1).

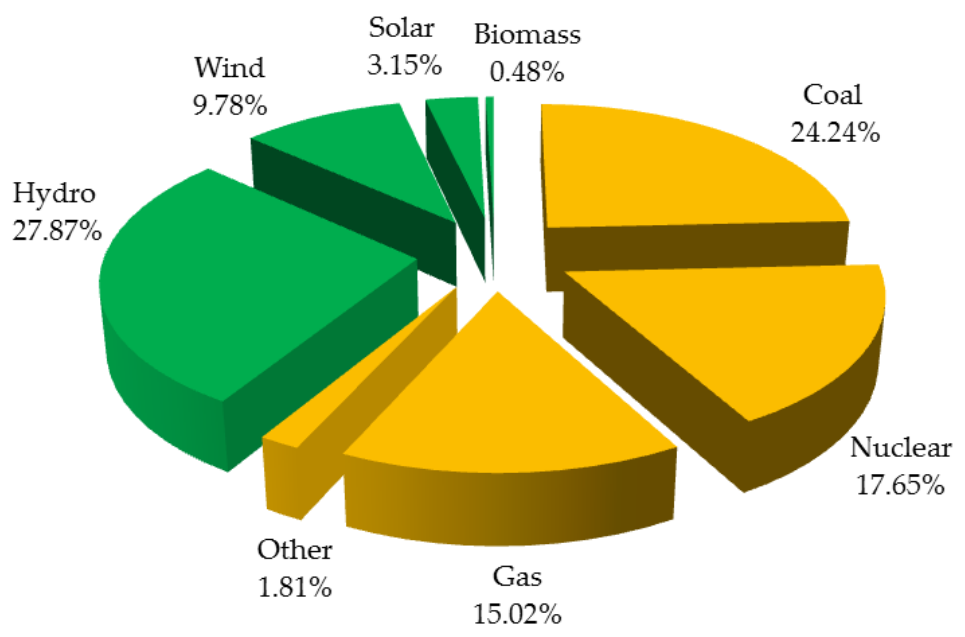

Figure 1: Romanian electricity production, 2018.

Romania's potential to generate renewable energy comprises water, wind, photovoltaic, biomass, and geothermal resources. The highest share consists of hydro energy, while wind energy comes second. Romania complies with the EU national target set 
for 2020 to ensure $24 \%$ of the country's energy consumption from renewable sources. The share already reached $23.9 \%$ in 2018, Romania being ranked 10th out of the 27 EU member states when comparing these shares [40].

This success can be attributed to the incentives included in the late 2000s in the Romanian energy policy. The most important financial support mechanism for the generation of electricity from renewable sources has been organized in Romania based on quota obligations, tradable green certificates (GCs), and price thresholds and ceilings. Electricity producers are required to present a specific number (or quota) of GCs, as per Law no. 220/2008.

Suppliers who do not comply with the yearly imposed quota need to pay a fee that corresponds to the amount of the nonpurchased GCs. The payment is directed towards Transelectrica, the power grid company. Consequently, as analysts observe, the price of the renewable energy increases steeply. It is composed of the actual price of electricity plus the costs of suppliers with GCs acquired, plus penalties in case of non-compliance [41].

Following the austerity in the years of the financial crisis and the loss of competitiveness of many industrial consumers, which were buying electricity at high prices, with GCs included in the acquisition cost, the Romanian government took the first steps in turning against producers of renewable energy in 2013. Subsequently, the market for green certificates collapsed following the substantial decrease in the yearly compulsory quota of electricity generated from renewable sources compared to the values set out in Law no. 220/2008 [42].

The remarkable progress by investors in the wind energy sector during the years 2010-2012 in installing new capacities, lured by the attractive support scheme applied from 2011 onwards, came to an abrupt halt in 2015, following two years of decreasing enthusiasm. This change in investor attitude can be easily observed from the evolution depicted in Figure 2 [23]. 


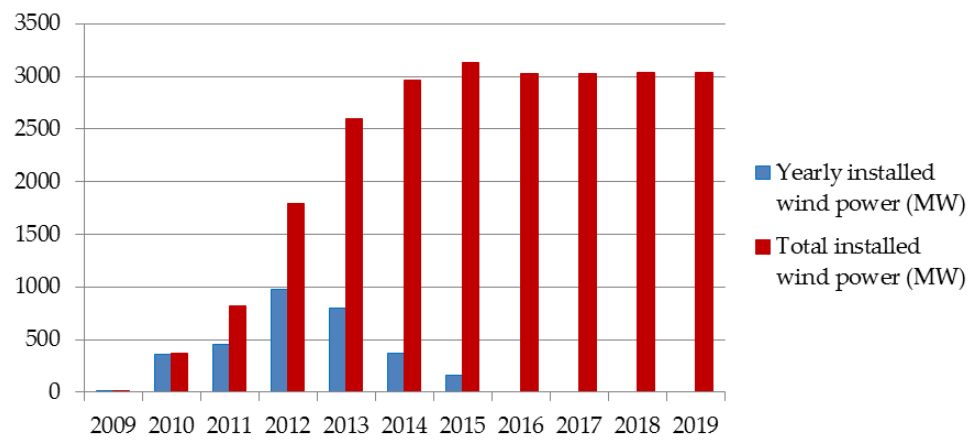

Figure 2: The evolution of wind power capacities installed in Romania.

The changes in the support scheme initiated in 2013, which reduced the number of issued GCs was the trigger of this phenomenon. Once several legal revisions were adopted after the year 2013, the development of the renewable energy market almost stopped, and all the major companies that invested in Romania (CEZ, ENEL Green Power, Verbund, EDP Renewables, to name just the top four), put their future investment plans on hold. The impact of the changes in the Romanian energy policy and their outcomes are investigated in depth in the next section.

\section{Results and Findings}

As a member state of the EU, Romania has transferred the EU program 20/20/20 and its goals into the national Law no. 220/2008, a law which has been approved by the Decision no. $4938 / 2011$ of the European Commission for state aid.

According to this law and taking into account that an investment in electricity barely pays off, renewable energy producers obtain a specific number of green certificates, in accordance with the energy produced and delivered into the energy network. These are calculated separately for each type of technology employed (three GCs for small hydro, two GCs for wind power, six GCs for solar power, for each MW delivered) and they are pegged to the internal rate of return, as indicated in Table 1 [43]. 
Table 1: Internal rate of return for technologies promoted by the support scheme.

\begin{tabular}{|l|l|}
\hline Technology & Decision C (2011) 4938 \\
\hline Wind power plants & $10.9 \%$ \\
\hline Small hydro plants & $10.2 \%$ \\
\hline Biomass co-generation & $10.5 \%$ \\
\hline Photovoltaic plants & $11.6 \%$ \\
\hline
\end{tabular}

It is mandatory for grid operators to allow access for renewable energy generators to their grids without shutting off certain plants. The costs for connecting a certain plant to the grid are incurred by the plant operator. According to the law, plant operators are entitled to priority when transmitting electricity from renewable energy. As a principle, grid operators are required to extend the network if there is demand from an operator, in the case that an extension is necessary. Grid operators, plant operators, or both will need to support the cost of the extension, depending on the specific part which has to be extended [44].

Stimulated by the regulations in place, domestic and foreign investors have built new power plants from renewable sources during 2010-2017 with a cumulative installed power of around $5000 \mathrm{MW}$. There are about 800 renewable energy producers registered in Romania, and their investments exceed EUR 8 billion. [45]. Currently, these investments ensure around 20\% of final gross electricity consumption in Romania. Moreover, during this period Romania transformed itself into a net energy exporter and the domestic wholesale price of energy decreased.

Unfortunately, Law no. 220/2008 underwent 11 changes over a decade. The system of stimulating the production of electricity from renewable energy was changed successively in the primary and secondary legislation, starting with the year 2013. The main prerequisites that determined policymakers to implement these changes relate to the broader political economy context and the relations between stakeholders. On the one hand, institutional rigidities of public authorities are not negligible. Strong lobbying activity on the part of the negatively affected traditional utilities and their trade unions, who oppose the expansion of renewable 
energy, put their fingerprint on decisions taken by public bodies. On the other hand, the dissatisfaction generated by the increase in electricity prices for industrial consumers (including the cost of GCs) led to ardent political and business debates.

The major changes that have been adopted include:

- The reduction in compulsory renewable energy quotas that benefit from the allocation of green certificates, starting with the year 2014;

- The reduction in the expiry deadline of green certificates from 16 months to 12 months;

- The delay in the possibility of trading green certificates.

The impact of these changes on producers was complex. Most of the investments in renewable energy were approved by the National Regulatory Authority for Energy (ANRE) and considered the generous provisions of the initial law. By issuing Emergency Ordinance no. 57/2013, the Romanian government reduced these quotas by $30 \%$, as a first measure. The reduction in acquisition quotas of green certificates generated a loss in their financial value. Subsequently, the support system comprising green certificates has become unsustainable for existing investments and has led to an excess of some 13 million GCs. Worse, as a second change, these certificates expired after 12 months, down from 16 months in the initial plan. Moreover, as a third measure, the Romanian government delayed the trading possibility of GCs, to a specific number: one for hydro power plants (max. $10 \mathrm{MW}$ ), one for wind installations, and two for photovoltaic parks. While this measure was intended to reduce the energy bills paid by industrial and household consumers, it also decreased the revenues of renewable energy producers by approximately one third [46].

Additionally, according to the revisions of the renewable energy support scheme during 2013-2015, for producers of electricity from renewable sources, with installed capacities above 250 MW, vs. $125 \mathrm{MW}$ as initially set, an individual clearance needs to be obtained from the European Commission. For installed capacities between $125 \mathrm{MW}$ and $250 \mathrm{MW}$, which have not 
benefitted from the renewable promotion system, an accreditation issued by ANRE is sufficient [47].

The successive legal changes that started in 2013 had a strong negative impact for electricity producers from renewable sources, generating significant financial losses, according to the financial statements compiled by the Ministry of Public Finance: around EUR 568 million in 2014, EUR 458 million in 2015, and EUR 389 million in 2016 [48]. Investors saw the value of their assets plunging as a consequence of falling revenues after these legal measures have been implemented, most of which impeded the further development of the renewable energy market.

According to local financial statements, in the year 2014 alone, the values of assets in the wind sector fell by EUR 337 million, followed by another reduction of 10\% in 2015 compared to the year before. The situation worsened further with assets falling by $13 \%$ in 2016 and by $10 \%$ in 2017 compared to the previous year [49].

Combined with falling revenues from green certificates, producers had to face increases in operating costs, most of them induced by policymakers, through measures such as:

- Government Decision no. 1202/2010, by which the cost of water entering turbines increased by 4.2 times in a very short period;

- A change in the Fiscal Code by which the pillars sustaining wind turbines were moved to the status of buildings and thereby were considered for local annual taxation;

- An order of 2014 by which participants in the centralized market of bilateral contracts were obliged to make offers of fixed value and deliver energy at constant power, leading to increased costs;

- A twenty-fold rise in the contribution to ANRE, by Emergency Ordinance no. 114/2018.

Following the frequent legal changes that started in 2013, when analyzing the overcompensation of renewable energy producers through GCs, the threshold for the return-on-investment set at 
aggregate level for each type of technology, although notified and approved by the European Commission, has drifted far apart from the real development of the energy market, thus becoming unfair [46].

The state aid was not distributed proportionately between renewable energy producers, due to the fact that most GCs were traded in the Market for Bilateral Contracts (PCBCV) and the Market for Bilateral Contracts Negotiated Directly (PCBCVND), as can be observed from data in Table 2 [46]. These deals were concluded by:

- Integrated companies that are both producers and suppliers and sign intra-group contracts;

- Small producers with installed power below $3 \mathrm{MW}$, who sell the energy in a package with GCs well below the next-daymarket value (the reference market for the calculus of revenues from energy in the overcompensation analysis), and suppliers in the market (to whom they transfer thus the state aid received).

Table 2: The situation of green certificates (GCs) and the share of deals in the GC market.

\begin{tabular}{|l|l|l|l|}
\hline Category & $\mathbf{2 0 1 8}$ & $\mathbf{2 0 1 9}$ & $\mathbf{2 0 2 0}$ \\
\hline Issued GCs (incl. deferred) & $16,012,491$ & $16,653,295$ & $17,000,000$ \\
\hline Stock of GCs & $11,446,473$ & $10,937,132$ & $9,071,458$ \\
\hline Valid GCs for trading & $27,258,964$ & $27,590,427$ & $26,071,458$ \\
\hline Sold GCs & $16,321,832$ & $18,518,969$ & $19,484,199$ \\
\hline$\%$ traded in PCSCV & $17 \%$ & $24 \%$ & $27 \%$ \\
\hline$\%$ traded in PCTCV & $1 \%$ & $2 \%$ & $2 \%$ \\
\hline$\%$ traded in PCBCV & $57 \%$ & $59 \%$ & $56 \%$ \\
\hline$\%$ traded in PCBCV -ND & $25 \%$ & $15 \%$ & $15 \%$ \\
\hline Final stock of GCs & $10,937,132$ & $9,071,458$ & $6,587,259$ \\
\hline Absorption rate & $59.88 \%$ & $67.12 \%$ & $74.73 \%$ \\
\hline
\end{tabular}

This mechanism led to an excessive number of GCs in the market (see Table 2). Consequently, due to low demand from suppliers, who filled in their quota of GCs from PCBCV and PCBCV-ND, non-integrated producers with installed power above $3 \mathrm{MW}$ were, in effect, thrown out of the market. They could sell their GCs in a transparent way only in a modest share 
of about 25\%, mostly in the Spot Centralized Market (PCSCV) and almost none in the Future Centralized Market (PCTCV), the rest of GCs remaining in stock, to be traded after 2027.

The financial support mechanism for new facilities producing electricity from renewable energy was stopped at the end of 2016. Since 2017, there is no longer a comprehensive subsidy mechanism in place for renewable energy producers. The National Energy Strategy of Romania, issued in 2017, foresees no further plans for another support scheme. However, the quota system is still valid for plants initiated before 2017 and will be in place until 2031.

Although the quota system is not available anymore for new facilities, these can still benefit from a subsidy through financing from the National Rural Development Program. Part of the European Agricultural Fund for Rural Development (EAFRD), this facility offers subsidies for agriculture, inside measure no. 4, called "Investment in physical assets". This program promotes the use of renewable energy for the private consumption needs of any farm [50].

Additionally, starting with 2017 an aid mechanism has been passed to stimulate energy generation from less conventional sources, including biogas, biomass, and geothermal energy. The support mechanism is implemented by the Ministry of Regional Development, Public Administration and European Funds. Its objective is to raise electricity and thermal energy generation from such sources by $60 \mathrm{MW}$ until the end of 2023 .

Another important update to the support scheme for renewable energy arrived in early 2017, stating that the conclusion of new bilateral contracts was not permitted anymore after August 2017. This was meant to prevent preferential trading and re-establish some balance between producers. Additionally, the new regulation clarified several legal uncertainties and ensured a stable and transparent character to the GC support mechanism. Thus, the recovery of deferred GCs will be performed from January 2018 until December 2025 in equal monthly stages, extending the period from the initial 2020 deadline [49]. 
Additionally, according to law, the suspended GCs during the period 2013-2014 will be issued starting with January 2021.

However, it is considered that in order to improve the predictability in the market for GCs that still remain to be transferred to suppliers of electricity and to foster the accuracy of business plans of producers who rely on the spot centralized market, further official clarifications and a periodic update on the future number of GCs to be traded is needed.

Moreover, Law no. 184/2018 featured the new "prosumer" concept, setting the legal base to stimulate the development of decentralized electricity production from small photovoltaic parks. Starting in 2019, the Administration of the Environmental Fund in Romania financed photovoltaic systems to a maximum 90\% of total costs, but not above EUR 4300 per household [50].

To complete the exploratory study and to obtain a multi-faceted view of the renewable energy market in Romania, a view grounded with practitioners in the field, a series of semistructured individual depth interviews with executives of renewable energy companies were conducted by the author during September-October 2019.

Given the sensitivity of current matters in the energy market, the relatively well-known position of companies in the sector and the rather small number of executives (close to 20) who agreed to answer the questions, the views of interviewees were expressed under anonymity. They were addressed a number of questions of which a relevant selection were used for the purpose of this paper (see Appendix at the end of the paper for the sample questions).

For a general consideration on the success of their investments made to date in the Romanian energy market, only about onethird of executives declared themselves satisfied. Most interviewees expressed a negative opinion. They complained that even after planning their projects according to a very strict investment and financial schedule, built in accordance with the legal framework infrastructure of the initial years (2010-2013), 
at present they are fighting hard to cover expenses and costs related to the particularities of the energy market in Romania.

The vast majority of respondents considered government bureaucracy and regulations to be very strict and not well motivated in their purpose. One interviewee even acknowledged that the company decided to give up some projects in the county of Constanta, because of the very difficult manner of collaborating with authorities at that time. Several executives explained that regulations are very demanding, making it difficult to understand the process flow. Therefore, the interviewees suggested the necessity of improvements in terms of stability, transparency, and predictability at administrative and regulatory levels. They also indicated the need for modern and innovative regulatory methodologies to be adopted where possible. They stressed the fact that opinions of experts in the sector and participants in public debates should be incorporated into the plans and policies designed by authorities.

A clearer commitment from policymakers towards respecting the deadlines and long-term planning coupled with grounded measures of implementation are badly needed. Some of the interviewees suggested a simplification of the procedures necessary for the deployment of power pants. Others recommended a leveling of the playing field in terms of policy, so as to recognize renewable energy as a standard component of the energy system.

Another subject under investigation regarded the ease of collaboration with domestic companies involved in the electricity market. While most of the interviewees did not complain about the cooperation with grid operators, some of the renewable energy producers were confronted with difficulties in their business relationship to grid and network operators. As opposed to the period 2011-2013, when there were so many projects in the sector that the grid operators were overloaded, afterwards, because of the changes in the support scheme, many of the planned projects were not fulfilled, but at the same time the grid was still kept occupied. 
Considering the greatest challenges, positive or negative with respect to doing business in Romania, the widespread opinion of interviewees was negative. Among the main challenges they mentioned was the lack of stability, transparency, and predictability of the administrative and regulatory framework. Managers also found bureaucracy in the whole administrative system to be huge and annoying. Some of the interviewees reckoned that the biggest (negative) surprise was when the government decided to reduce the revenues of renewable energy producers.

As a widespread opinion, executives supported the view which resulted from secondary data that there are too many changes in the legal framework, which have a direct impact on their nonpredictable activity. Some of the managers were exasperated that they cannot even follow their own budgets.

In this context, the greatest risks of being involved in the Romanian energy market were associated with the support scheme, balancing the costs, nonprofessional authorities, and the many changes and interpretations of the law. Legal, regulatory and fiscal instability and unpredictability were cited most frequently by respondents amongst the greatest risks within the renewable energy market, as factors that jeopardize investments which imply high risks and are usually undertaken in the long term.

As a worrying result, about two-thirds of executives regarded the investments made by their companies in Romania as not financially sustainable in the long term. They expressed concern at the lack of an attractive energy policy in the present conditions. One of the respondents feared that the recovery of investment is not possible and not predictable, while others commented that sub-sectors within the market may carry a different outcome. Investments undertaken in the wind sector are generally viewed as not being financially sustainable in the mid and long term, in the current outlook.

In a separate investigation, Atanasoae and Pentiuc (2017) performed a cost-benefit analysis by measuring the internal rate 
of return at three different moments (at the beginning of the support scheme, during the scheme, but with changed prices and after the reduction in the number of GCs). For all the four types of renewable energy sources analyzed, namely wind, solar, hydro and biomass, the internal rate of return plunged from positive to negative values [51].

For renewable energy producers, especially in the wind sector, the analysis of financial overcompensation so as to determine the return of investment, performed by assessing investment costs, operating costs, and revenues from the sale of energy and GCs, revealed a gap between two categories:

- Integrated producers benefitted $100 \%$ from GCs because they concluded intra-group contracts according to the legislation prior to Emergency Ordinance no. 57/2013;

- Non-integrated producers benefitted from only about onequarter of GCs, the rest of them being stocked until the end of the support scheme.

Thus, non-integrated wind energy producers accumulated large financial losses due to expired GCs. During the years 20152018 , the volume of expired GCs was close to 2.3 million units, with a total value of around EUR 66.8 million [46].

At the present moment, the renewable energy sector is, in fact, undercompensated, as a report from the National Regulatory Authority demonstrates [52]. Thus, one suggestion would be that all remaining GCs should be traded in the single centralized spot market, so that most producers can benefit fairly from the state aid.

In practice, a sector initially stimulated through the support scheme designed by the EU was brought by Romanian policymakers into a general state of insolvency; more and more investors needed to supplement money on their own, so as to sustain current operations. Tens of wind and solar parks struggled financially and some of the photovoltaic power producers withdrew from the energy market. 
An association of 10 companies of different nationalities and ownership, led by an Austrian group, all active in the renewable energy market, mostly photovoltaic projects, even filed a lawsuit against the Romanian Ministry of Finance for the abrupt change of laws at the International Centre for Settlement of Investment Disputes in the United States [53]. To date, the case is still pending, being in the documentation phase. As a consequence of their worsening financial performance over the course of the last few years, companies made important downward adjustments to their fixed assets.

A major concern arose during mid-2019 with a new Emergency Ordinance project that obliged companies to establish the net asset up to a level of at least half of shared capital. This raised the alarm for a lot of producers because they were unable to cope with this new condition. Renewable energy producers usually invested significant sums by contributing to the shared capital in the form of credits and loans from shareholders. They established the net assets by converting debts to shareholders, which has led to a substantial increase in shared capital.

Considering that the market is highly regulated, combined with the decreasing value of net assets (due to losses and negative adjustment of fixed assets), there will be few possibilities for companies to comply with the condition that net asset is at least half of shared capital [46]. To date, the new Ordinance is still pending approval from the Romanian Parliament.

The Association of Renewable Energy Producers (PATRES), which includes more than 100 non-integrated renewable energy companies, totaling more than $1800 \mathrm{MW}$ installed power and investments in the Romanian energy sector of around EUR 2 billion. Some authors tried to raise awareness and to shelter producers [45]. The alternative proposal was to drop the projected change in the law and substitute it with a compulsory provision of installing a positive net asset, a scheme that has been used in other EU member states. 


\section{Conclusions}

To sum up, from the exploratory analysis of the evolution of the Romanian renewable energy market and the consistent opinions expressed by the interviewed executives, some final conclusions can be drawn.

It seems clear that the development of energy generation from renewable sources is still very dependent on public support in most of the European Union member states and, as such, vulnerable to political changes. Romania makes no exception to this. There has been strong dissatisfaction with the changes in renewable energy policy from 2014 onwards, because of the major financial losses incurred by several producers after the date when the number of issued green certificates (GCs) decreased and the support scheme was partially abandoned.

The frequent changes of the regulations, with no adequate prior impact study, without a proper consultation of the actors involved in the renewable energy market, has led to a profound mistrust of the producers in the field. Moreover, changing 'the rules of the game in the middle of the game', within a very competitive international environment, was a poor signal given to investors interested in placing their money in the Romanian energy sector.

This is a critical element, because the renewable energy sector needs high initial capital investment; it carries high risks and brings long-term investment returns [54]. Positive returns are obtained only after the first few years and the Romanian government does not seem prepared to authorize such massive investments. Taking all these factors into account, it seemed not a proper time to discourage private investors in the field.

In its initial stages, Romania was one the first European countries to implement GCs. However, most EU member states now use a feed-in tariff system, considered cheaper and easier to operate. Some countries, such as Poland, switched from the support scheme by means of GCs, which was in operation since 2005, to an auction system with reference prices starting in 2016. 
According to this system, offers with prices superior to the reference price are neglected and the auction is won by the bidders offering the lowest price for renewable energy until the imposed upper limit for a given auction is used up [55].

In Romania, according to the regulations, the GC support scheme for renewable energy is valid for a period of 15 years after the new facilities in wind or solar parks start functioning effectively. Thus, a change to feed-in tariff is highly improbable in the Romanian market. The GC scheme was devised on a longterm basis, and already being in operation, it is now almost impossible to change it in Romania.

Alternatively to the GC scheme which has become unsustainable, a state aid scheme could be designed to support energy producers from renewable sources and restore investors' appetite for development. This would entail the payment of a fixed bonus specific to the category of technology, added to the average price resulting from the trade in the centralized market for electricity.

More consistent investments in inter-connectors to encourage supply to flow to price would also be an important step forward. These investments in inter-connectors could enable the integration into a competitive and well-functioning internal energy market of the EU, which is a necessary condition to achieve sustainability, efficiency, and security of the energy supply.

To close in on its goals, the EU wants to guarantee at least $15 \%$ electricity inter-connection levels between neighboring member states. Thus, EU law requires that each country elaborates a 10year national plan for energy and climate, which should include its own strategy for reaching the targets [56]. Such measures became highly relevant, as the new Energy Strategy of the EU for 2020-2030, voted by the European Parliament in 2018 set a new national mandatory target of a $35 \%$ energy share from renewable sources in the total gross consumption of electricity by the year 2030 . 
The contribution of this paper to the literature in the field consists of an assessment of the profound changes in the Romanian renewable energy market, the critical analysis of the regulatory framework, and the recommendations issued for policymaking. The value added of the conducted research in the European context consists of developing important insights about the attempts for a more robust renewable energy policy fundament, capable to withstand political lobbying and pressure from various stakeholders in the short term. Several countries in the EU, for example Spain and the Czech Republic, have experienced a similar up-and-down evolution in their renewable energy sector, similarly to Romania [16]. Therefore, along with growing research and development in the field and adding more modern infrastructure to the energy system, policy measures in most European countries should integrate awareness-raising programs on the necessary shift to renewable energy, coupled with funding, training programs and relocation support for employees made redundant by the new, green energy technologies.

However, some limitations of the research reside in the onecountry study and the relatively narrow base of respondents from the business environment. As with all qualitative research, a main limitation stems from the fact that the obtained results cannot be applied to a larger scale. Nevertheless, this type of exploratory study could be extended to neighboring countries in the region, so as to pave the way for a comparative assessment. To address the limits of the present research, the author also considers building up quantitative research that allows for the extension of the results.

The findings of the present research may prove significant for a better decision-making in the difficult times that renewable energy producers currently encounter in the market. The suggested recommendations, if implemented, could foster the trust of current and potential investors in a more predictable future for their financial forecasts.

Further research should be dedicated to find the optimum mix of public policies towards meeting the ambitious goal of Europe- 
to become the first climate-neutral continent by the year 2050 . Up to the present moment, the EU has employed an ambitious program based on the market-rules to mitigate greenhouse gas emissions. Subsequently, modern power lines are deployed at regional level to ensure a solid and integrated energy market [57]. Massive decarbonisation will only work when accompanied by strong technological developments. To fulfill this challenge, the European Union plans to allow the free flow of energy between EU member states, thus diminishing the dominant position of domestic monopolies.

\section{References}

1. Prados MJ. Renewable energy policy and landscape management in Andalusia, Spain: The facts. Energy Policy. 2010; 38: 6900-6909.

2. EC. 2020 Climate \& Energy Package. Brussels: European Commission. 2012.

3. Melenciuc S. Romania ranks among EU's best performers in terms of renewable energy production. Business Review, 2018. Available online at: https://businessreview.eu/energy/romania-ranks-among-eus-bestperformers-in-terms-of-renewable-energy-production185009

4. Colesca SE, Ciocoiu CN. An overview of the Romanian renewable energy sector. Renew. Sustain. Energy Rev. 2013; 24: 149-158.

5. Scarlat N, Dallemand JF, Monforti-Ferrario F, Banja M, Motola V. Renewable energy policy framework and bioenergy contribution in the European Union-An overview from National Renewable Energy Action Plans and Progress Reports. Renew. Sustain. Energy Rev. 2015; 51: 969-985.

6. Paska J, Surma T. Electricity generation from renewable energy sources in Poland. Renew. Energy. 2014; 71: 286294.

7. Muhammed G, Tekbiyik-Ersoy N. Development of Renewable Energy in China, USA, and Brazil: A Comparative Study on Renewable Energy Policies. Sustainability. 2020; 12: 9136. 
8. Balibrea-Iniesta J. Economic Analysis of Renewable Energy Regulation in France: A Case Study for Photovoltaic Plants Based on Real Options. Energies. 2020; 13: 2760.

9. Jacobs D. Renewable Energy Policy Convergence in the EU: The Evolution of Feed-in Tariffs in Germany, Spain and France. London: Routledge. 2016.

10. Bechberger $M$, Reiche $D$. Renewable energy policy in Germany: Pioneering and exemplary regulations. Energy Sustain. Dev. 2004; 8: 47-57.

11. Wustenhagen R, Bilharz M. Green energy market development in Germany: Effective public policy and emerging customer demand. Energy Policy. 2006; 34: 16811696.

12. IEA. Germany 2020: Energy Policy Review. Paris: International Energy Agency. 2020.

13. Renn O, Marshall JP. Coal, nuclear and renewable energy policies in Germany: From the 1950s to the "Energiewende." Energy Policy. 2016; 99: 224-232.

14. Raybould B, Cheung WM, Connor C, Butcher R. An investigation into UK government policy and legislation to renewable energy and greenhouse gas reduction commitments. Clean Technol. Environ. Policy. 2019; 22: 371-387.

15. Velasco MJP. Renewable energy policy and landscape management in Andalusia, Spain: The facts. Energy Policy. 2010; 38: 6900-6909.

16. Gurtler K, Postpischil R, Quitzow R. The dismantling of renewable energy policies: The cases of Spain and the Czech Republic. Energy Policy. 2019; 133: 110881.

17. Martinez Alonso PM, Hewitt RJ, Pacheco JD, Bermejo LR, Jimenez $\mathrm{VH}$, et al. Losing the roadmap: Renewable energy paralysis in Spain and its implications for the EU low carbon economy. Renew. Energy. 2016; 89: 680-694.

18. IRENA. REmap 2030: Renewable Energy Prospects for Poland. Abu Dhabi: International Renewable Energy Agency. 2015.

19. Bianco V, Manca O, Nardini S, Minea AA. An Analysis of the Electricity Sector in Romania. Energy Sources Part B Econ. Plan. Policy. 2013; 9: 149-155. 
20. Haar LN, Marinescu N. Energy policy and European utilities' strategy: Lessons from the liberalisation and privatisation of the energy sector in Romania. Energy Policy. 2011; 39: 2245-2255.

21. Dusmanescu D, Andrei J, Subic J. Scenario for Implementation of Renewable Energy Sources in Romania. Procedia Econ. Financ. 2014; 8: 300-305.

22. Stefan DC, Martis C, Cirstea A, Constantinescu-Dobra A, Fülöp MT. Current Situation and Future Perspectives of the Romanian Renewable Energy. Energies. 2018; 11: 3289.

23. Dragomir G, Serban A, Nastase G, Brezeanu AI. Wind energy in Romania: A review from 2009 to 2016. Renew. Sustain. Energy Rev. 2016; 64: 129-143.

24. EY. Renewable Energy Country Attractiveness Indices. London: Ernst \& Young. 2012.

25. Zamfir A, Colesca SE, Corbos RA. Public policies to support the development of renewable energy in Romania: A review. Renew. Sustain. Energy Rev. 2016; 58: 87-106.

26. Busu M, Clodnițchi R, Mureșan ML. A correlation analysis of the spot market prices of the Romanian electricity sector. Manag. Mark. Challenges Knowl. Soc. 2019; 14: 150-162.

27. Campeanu V, Pencea S. Renewable Energy Sources in Romania: From a "Paradise" of Investors to a Possible Abandon or to Another Boom? The Impact of a New Paradigm in Romanian Renewable Sources Policy. Procedia Econ. Finance. 2014; 8: 129-137.

28. Duhaneanu M, Marin F. Transforming Energy Sector to Sustain Growth: Business Opportunities in Romania's Energy Sector. In Proceedings of the International Conference of the Institute for Business Administration. Bucharest, Romania. 2013.

29. Marinescu N. Wind Energy in the EU: How Does Romania Fare? Ann. Constantin Brancusi Univ. Targu-Jiu. 2017; 3: 83-87.

30. Grodek-Szostak Z, Luc M, Szelag-Sikora A, Sikora J, Niemiec $M$, et al. Promotion of RES in a Technology Transfer Network. Case Study of the Enterprise Europe Network. Energies. 2020; 13: 3445.

31. Kolagar M, Hosseini SMH, Felegari R, Fattahi P. Policymaking for renewable energy sources in search of 
sustainable development: A hybrid DEA-FBWM approach. Environ. Syst. Decis. 2020; 40: 485-509.

32. Choi G, Heo E, Lee CY. Dynamic Economic Analysis of Subsidies for New and Renewable Energy in South Korea. Sustainability. 2018; 10: 1832.

33. Maqbool AS, Baetens J, Lotfi S, Vandevelde L, Van Eetvelde G. Assessing Financial and Flexibility Incentives for Integrating Wind Energy in the Grid Via Agent-Based Modeling. Energies. 2019; 12: 4314.

34. Moshiri S, Lechtenbohmer S. Sustainable Energy Strategy for Iran, Wuppertal Institut fur Klima. Wuppertal: Umwelt, Energie. 2015.

35. Wind Europe. Wind in Power 2017-Annual Combined Onshore and Offshore Wind Energy Statistics. 2018. Available online at: https://windeurope.org/wpcontent/uploads/files/about-wind/statistics/WindEuropeAnnual-Statistics-2017.pdf

36. Eurostat. Renewable Energy Statistics. Eurostat-Statistics Explained. Luxembourg: Eurostat Press Office. 2020.

37. Simon F. Six EU Countries Join Call for 100\% Renewable Energy Scenario. Euractiv, 2020. Available online at: https://www.euractiv.com/section/energy/news/six-eucountries-join-call-for-100-renewable-energy-scenario/

38. IRENA. Global Energy Transformation: A Roadmap to 2050. Abu Dhabi: International Renewable Energy Agency. 2019.

39. ANRE. Report Concerning the Results of Monitoring the Electrical Energy Market for the Year 2018. Bucharest: The National Authority for Energy Regulations. 2019.

40. Eurostat. Renewable Energy Tables and Figures-Second Update. Luxembourg: Eurostat Press Office. 2020.

41. Popa E. The Challenge of Green Energy. Bucharest: Green Report. 2010; 31-34.

42. Sebesi A. Power Up and Down. Business Review, 2015. Available online: https://business-review.eu/featured/powerup-and-down-91559

43. EC. Decision No. 4938 - State Aid SA. 33134 2011/N-RO. Brussels: European Commission. 2011.

44. RES LEGAL Europe. Renewable Energy Policy Database and Support. Brussels: European Commission. 2019. 
45. Lefter V. Future of Romania's Renewable Energy Industry. In Proceedings of the 10th Energy Day Conference. Brasov, Romania. 2018.

46. PATRES. Information Memo about the State of the Sector Addressed to the Ministry of Public Finance and ANRE. Bucharest: The Patron Organization of Renewable Energy Producers in Romania. 2019.

47. EY. Financial Position and Performance of the Romanian Wind Power Sector in 2015. Bucharest: Ernst \& Young. 2016.

48. MFP. Financial Statements in the Energy Sector. Bucharest: Ministry of Public Finance.2018.

49. EY. Financial Analysis of the Romanian Wind Power Sector: Overview for Year 2016-2018. Bucharest: Ernst\&Young. 2018.

50. Blajin C. Romania: Update on the Regulations on Renewable Energy Generation. Brussels: European Commission. 2019.

51. Atanasoae P, Pentiuc R. Considerations on the Green Certificate Support System for Electricity Production from Renewable Energy Sources. Proc. Eng. 2017; 181: 796-803.

52. ANRE. Report Concerning the Analysis of Overcompensation of the Promotion System through Green Certificates of Electrical Energy Produced from Renewable Sources for the Year 2018. The National Authority for Energy Regulations. Bucharest, Romania, 2018.

53. ICSID. LSG Building Solutions GmbH and others v. Romania (ICSID Case No. ARB/18/19), International Centre for Settlement of Investment Disputes. Washington, DC: World Bank Group. 2020.

54. Lyu X, Shi A. Research on the Renewable Energy Industry Financing Efficiency Assessment and Mode Selection. Sustainability. 2018; 10: 222.

55. Iglinski B, Iglinska A, Kozinski G, Skrzatek M, Buczkowski R. Wind energy in Poland-History, current state, survey. Renewable Energy Sources Act. SWOT analysis. Renew. Sustain. Energy Rev. 2016; 64: 19-33.

56. EC. Romania - Summary of the Commission assessment of the draft National Energy and Climate Plan 2021-2030. Brussels: European Commission. 2019. 
57. Strielkowski W, Lisin E, Gryshova I. Climate Policy of the European Union: What to Expect from the Paris Agreement? Rom. J. Eur. Aff. 2016; 16: 68-77.

\section{Appendix}

Some of the questions for the non-structured interviews with senior executives of renewable energy companies in Romania are sampled here:

1. It is now some years since your company launched various investments and other activities in Romania. With the benefit of hindsight, would you describe the results as successful?

2. How about government bureaucracy and regulations; how have you found them?

3. Have network and grid operators been generally helpful in facilitating your business entry and expansion?

4. What would you say were the greatest surprises and challenges, positive or negative with respect to doing business in Romania?

5. What do you regard as some of the greatest risks of being involved in the Romanian energy market?

6. Looking to the long term, do you regard your investments in Romania as financially sustainable? 